\title{
Self-Compassion And Emotional Maturity Of Street Children Assisted By KKSP Medan
}

\author{
Indri Kemala Nasution, Liza Marini, Rahma Yurliani \\ Departement of Developmental Psychology, Faculty of Psychology \\ University of Sumatera Utara \\ Medan, Indonesia \\ E-mail :ndi.kemala@gmail.com,liza1@usu.ac.id,rahma_yurliani@usu.ac.id
}

\begin{abstract}
This research aimed to determine the self-compassion and emotional maturity of street children assisted by KKSP (KelompokKerjaSosialPerkotaan) Medan. The study involved 300 street children selected using incidental sampling techniques. The teenagers involved in this study are street children aged 12-18 years old and most of them are assisted by the KelompokKerjaSosialPerkotaan (KKSP) Medan. The data was collected through questionnaires about self-compassion and emotional maturity of street children. The self-compassion scale was developed based on self-compassion theory by Kristin Neff (2015), consisted of three components: self-kindness vs. self-judgment, common humanity vs. isolation, and mindfulness vs. over-identification. Emotional maturity scale was developed based on the characteristics of emotional maturity according to Hurlock (2004) is emotional control, selfunderstanding and the use of critical mental functions. The results showed that subjects were categorized to the low self-compassion category is $1 \%$, moderate self-compassion category is $39 \%$ and high self-compassion category is $60 \%$. While the results of emotional maturity showed that no subject were categorized of low emotional maturity. The subjects were category to the moderate social maturity is $56 \%$ and high social maturity is $44 \%$. In other words, it can be concluded that the largest group in self-compassion is in the high category and the emotional maturity is in medium.
\end{abstract}

Keywords: self-compassion; emotional maturity; street children

\section{INTRODUCTION}

The phenomenon of street children has actually developed over many years, but now the world is increasingly concerned, along with the increasing number of street children in various major cities in the world. Street children is a person under the age of 18 who spends most or all of his time on the streets by engaging in activities to earn money or to sustain his life (Shalahuddin, 2010).

Street children have various ways to meet their economic needs. Research conducted by the Indonesian Institute of Sciences and the Ministry of Social Affairs of street children showed that street children choose to work as sellers of snacks, soft drinks, newspaper sellers, shoeshine, street singers, scavengers, angkot (city transport) sweepers and beggars (Hairani et al, 2006). Their efforts are generally for daily food needs, helping their family's economy, as well as to finance and continue their education (KKSP, Personal Communication).
Street children in the city of Medan in general are young children, which generally belonged in developmental age of early childhood, late childhood, and adolescence(KKSP, Personal Communication). Adolescence is not an easy phase to pass. Many changes have to be faced both on physical and psychological development. In that period of age, a child is undergoing puberty and is also in the search for identity (Erikson in Papalia, 2007).

At a relatively young age, there are so many impacts thatwill be experienced by street children. One of the impacts is living on the streets will generally lead to pessimistic attitude on street children. Another thing that is common in street children is that they will experience a confident crisis which will cause a high sensitive attitude to emerge (Suhartini, 2008).

The life of street children does not always have a negative impact, for some street children there are also positive impacts, for example children became hard-working because they are accustomed to heat and rain, street children can learn to work alone, be responsible and able to 
help the economy of their parents (Sarwoto, 2002). Holding on to the responsibilities underlying their economic problems, some of them still prioritize both formal and non-formal education. Some street children in Medan still in school in the morning and after school they will continue their responsibilities with their usual various types of work (KKSP, Personal Communication). For children who are unable to undertake formal education, they still can take the non-formal education provided by the KKSP foundation. KKSP Foundation is a foundation in Medan that focuses on raising awareness to children who are in difficult situation and aiming to give children basic rights, one of them is education.

When they become street children, some of them can also feel the happiness of what they are going through. Research conducted by Mardayeti (2013) explains that street children feel that he can feel happiness while being together with his friends, because according to him, his friends are able to pay attention to him and with his friends he can share all the problems that happened. Neff's (2013) study also explains that individuals who have self-compassion will exhibit a more positive relationship behavior than those who do not have self-compassion.

Self-compassion is a concept defined by Kristin Neff as affection related to the individual self as the object of attention when confronted with negative events (Neff, 2003a). Neff (2009) mentioned that self-compassion involves the need to manage personal health and well-being, and encourage initiatives to make changes in life. Lary et al., (2007) also stated that individuals with selfcompassion will accept the fact that they are deficient and imperfect, and they are responsible for what they do. Self-compassion will lead individuals to good emotional competence, as described in Ramdhani's (2014) study which stated that there is a major influence provided by self-compassion to emotional competence, it can be seen from its appropriateness to moral character, moral code and moral rule, then one can behave adaptively and being emotionally competent. It is in line with self-compassion that has a positive relationship with a person's psychological adaptation function (Neff, Rude \& Kirkpatrick, 2007).

Adjustment of a teenager to live on the streets also desperately needs emotional maturity so that he can live his days well and not affected by the environment. Emotions color the way people think in the face of conflict (Lazarus, 1991). But when emotions have reached such a high intensity, people become difficult to think efficiently. Thus, emotional maturity has a very important role in order to think maturely, well and objectively. Emotional maturity is a good self-control ability, the ability to express emotions appropriately or in accordance with the circumstances that encountered, able to adapt, able to accept various characters of people and situations and able to give the right reaction in accordance with the demands faced, and able to take decisions that are based on considerations so its not easy to fluctuate (Hurlock, 2007).

Individuals with emotional maturity means individuals can place the potential that they develop in a condition of growth, where the real demands of adult life can be overcome in an effective and healthy way (Schneiders in Kurniawan, 1995). Individuals with emotional maturity are able to accept responsibility for changes in their lives as a challenge rather than regard it as a burden, and with confidence trying to find the solution of the problem in ways that are safe for themselves and the environment, and socially acceptable (Hurlock, 2007).

\section{RESEARCH METHODS}

This study used descriptive method that aimed to provide a description of the research's subject. Based on data from the variables obtained from the subjects that studied and not intended for hypothesis testing. The sample used in this study is a sample that matches the characteristics of the population, namely: street children, adolescents aged 12-18 years and domiciled in Medan. The sampling technique used in this research is incidental sampling technique. The data were collected using a Self-Compassion scale developed based on self-compassion theory by Kristin Neff (2015) and with an emotional maturity scale developed based on the characteristics of emotional maturity according to Hurlock (2004). 
Measuring tool's reliability is measured by using Cronbach Alpha technique assisted with the SPSS version 17.0 for Windows program.

\section{RESULTS AND DISCUSSION}

The results showed that subjects were categorized to the low self-compassion category as much as $1 \%$, moderate self-compassion category as much as $39 \%$ and high self-compassion category as much as $60 \%$. While the results of emotional maturity showed that no subject were categorized to the category of low emotional maturity, but categorized into the moderate emotional maturity category as much as $56 \%$ and categorized to the high emotional maturity category as much as $44 \%$. If categorization based on its aspects were viewed, it can be seen that the five aspects of selfcompassion, namely Self-kindness, Self-judgment, Common humanity, Isolation and Mindfulness on most subjects are high. While from the categories in the emotional maturity aspect, it can be seen that the aspects of emotional control and the use of mental crisis on most subjects is high, while the aspects of self-understanding on most subjects are moderate.

\section{CONCLUSIONS AND RECOMMENDATIONS}

This research aimed to determine the selfimage and emotional maturity of KelompokKerjaSosialPerkotaan (KKSP - Urban Social Work Group) Medan's assisted street children. The study involved 300 street children selected using incidental sampling techniques. Street children who are involved here are street children aged 12-18 years old and domiciled in the city of Medan. The data were collected through self-compassion scale questionnaires developed based on self-compassion theory by Kristin Neff (2015) and with emotional maturity scale developed based on emotional maturity characteristics according to Hurlock (2004). The results showed that subjects were categorized to the low self-compassion category as much as $1 \%$, moderate self-compassion category as much as $39 \%$ and high self-compassion category as much as $60 \%$. While the results of emotional maturity showed that no subject were categorized to the category of low emotional maturity, but categorized into the moderate emotional maturity category as much as $56 \%$ and categorized to the high emotional maturity category as much as $44 \%$. If categorization based on its aspects were viewed, it can be seen that the five aspects of selfcompassion, namely Self-kindness, Self-judgment, Common humanity, Isolation and Mindfulness on most subjects are high. While from the categories in the emotional maturity aspect, it can be seen that the aspects of emotional control and the use of mental crisis on most subjects is high, while the aspects of self-understanding on most subjects are moderate.

\section{REFERENCES}

[1] Hairana, dkk. 2006. Faktor Dominan Anak Menjadi Anak Jalanan di Kota Medan. Jurnal Studi Pembangunan, April 2006, Volume 1, Nomor 2. Medan: Universitas Sumatera Utara.

[2] Hurlock, Elizabeth, B., E.B. (2007). Psikologi Perkembangan : suatu pendekatan Sepanjang rentang Rehidupan (edisi ke-5). Jakarta: Penerbit Erlangga.

[3] Mardayeti, Desfia. 2013. Gambaran Kebahagiaan pada Anak Jalanan (tidak diterbitkan).

[4] Neff, K. D. (2003). Self-compassion: An alternative conceptualization of a healthy attitude toward oneself. Self and Identity, 2, 85102. DOI: $10.1080 / 15298860390129863$.

[5] Neff, K. D. (2003a). The development and validation of a scale to measure self-compassion. Self and Identity, 2,223-250.DOI: 10.1080/15298860390209035.

[6] Neff, K. D., \& Rude, S. S., \& Kirkpatrick, K. (2007). An examination of self-compassionin relation to positive psychological functioning and personality traits. Journal of Research in Personality, 41, 908-916.

[7] Neff, K.D \& Vonk,R. (2009). Self compassion versus global swelf esteem. two different ways of relating tp oneself. Journal of Personality 77128.

[8] Neff, K.D. (2011). Self compassion : stop beating yourself up and leave insecurity behind. New York: Harper Collins Publisher.

[9] Shalahuddin, Odi. (2010). Fenomena Anak Jalanan Kota Medan; Problematika dan Solusinya (Sebuah studi tematik terhadap permasalahan Anak Jalanan; Antara tuntutan dan kebebasan hidup). https://odishalahuddin.wordpress.com/2010/ 01704/anak-jalanan-studi-kasus-ataspersoalan-sosial/. Diakses pada 30 Oktober 2016.

[10] Suhartini, Tina (2008). Strategi Bertahan Hidup Anak Jalan (Kasus: Anak Jalanan di Kota Bogor, Provinsi Jawa Barat). Skripsi. Bogor: Institut Pertanian Bogor.

[11] Lazarus, Richard. (1991). Emotion and Adaptation. New York: Oxford University Press

[12] Papalia, D. E, Olds, S. W., Feldman R. D. (2007). Human Development (10th ed.). New York: Mc Graw Hill Inc. 